\title{
"Does Adwa have a Colonial Legacy? Assessing the viability of the Colonial Thesis for Understanding Late Nineteenth and Early Twentieth Century Ethiopia"
}

\author{
Brian J. Yates*
}

\begin{abstract}
For many, the Ethiopian victory at Adwa was an African victory over European colonialism, but some scholars have reimagined the triumph as an example of African colonialism in recent years. This view culminates in the colonial thesis. This colonial thesis casts Menilek II of Shäwa (r.1888-1913) as a colonizer of Southern groups in present-day Ethiopia and posits his state as a foreign colonial power. This view is one of the theoretical underpinnings of the present Ethiopian ethnic federalism and many ethnolinguistic nationalist movements. One of the ways that it impacts identities, as the Ethiopian scholar Maimire Mennasemay puts it, ". . . ontologizes ethnic identity and falsely represents Ethiopia as a collection of discrete, ethnic communities, brought together by 'Amhara colonialism."' The scholar Mahmoud Mamdani builds on this view by arguing that transforming identities (politicizing nativity) was essential in governing colonial empires. In other words, the colonial government invented settlers and natives in their territories and treated them accordingly. In essence, this essay details the identities that were produced as a result of Ethiopia's victory at Adwa and argues that while oppression accompanied the conquest of territories North, East, West, and South of Menilek's native Shäwan province, Menilek's government did not produce identities to make power exclusive for one group as displayed at both the participation at the battle and in the administration that the victory preserved.
\end{abstract}

Keywords: Ethiopia, colonialism, Adwa, Menilek, nativism

DOI: https://dx.doi.org/10.4314/ejossah.v17i1.4

\footnotetext{
*Associate Professor, Department of History, Saint Joseph's University, Email: byates@sju.edu, Tel. Office: 1610660 3353, Philadelphia, PA (USA)
}

This work is licensed to the publisher under the Creative CommonsAttribution-NonCommercialNoDerivs License. 


\section{Introduction}

Scholars have often taken Ethiopia out of its African continent due to its lack of a colonial legacy and its challenge to simplistic, skewed, and homogenous notions of Africa. One of the many contributions of the last few decades of Ethiopian studies is the increased efforts to situate Ethiopia in its African context. One of the ways, as Maimire Mennasemay puts it, is the colonial thesis, “. . . that ontologizes ethnic identity and falsely represents Ethiopia as a collection of discrete, ethnic communities, brought together by "Amhara colonialism." (2005, p. 270) This colonial thesis imagines Menilek II of Shäwa (r.1888-1913) as a colonizer of Southern groups in present-day Ethiopia. This ideology is a factor in Ethiopia's present-day ethnic federalism (Maimire, 2005, pp. 276-9). This essay focuses on assessing whether or not the identities produced after the battle of Adwa (e.g., Amhara, Ethiopian, Oromo, Abyssinian) and/or the frameworks of identities (e.g., native, settler, subject, colonist) that colonialism produced were prevalent in Menilek's Ethiopia. Mahmoud Mamdani's work, Define and Rule (2012), will be the theoretical underpinning for this essay. I argue that the multi-ethnic participation at Adwa proved that even newly conquered subjects had a stake in Menilek's modernizing that the victory at Adwa preserved.

A vital aspect of the colonial thesis is the argument that the identities created after the battle of Adwa are similar to those made in the colonies throughout the African continent in the late $19^{\text {th }}$ and $20^{\text {th }}$ centuries. Mamdani writes on the nature of these identities, "Tribalism [that Colonialism produces] is reified ethnicity. It is culture pinned down to a homeland, culture in fixity, politicized, so that it does not move" (Mamdani, 2012, p. 7). These notions of identity are prevalent throughout Ethiopian studies, and the lived experiences of those in the $20^{\text {th }}$ and $21^{\text {st }}$ centuries. However, as Mamdani notes in a 2019 New York Times article, this characterization of Ethiopia's history is anachronistic. It assumed that all Southern groups were a conquered native tribe before Menilek's expansion. This essay argues that Menilek's Ethiopia is defined by the elasticity of the Habäsha identity, centuries of interactions between groups in Ethiopia, and lack of the desire to create and maintain permanent boundaries between people. For these reasons, tribalism and creating "natives" were not significant factors in administering the Ethiopian Empire after the victory at Adwa. They are, however, a vital component of the present Ethiopian state, where Mamdani notes, "national belonging gave way to tribal identity as the real meaning of citizenship" (Mamdani, 2019).

One of the consequences of the fall of the Solomonic dynasty in the late 20th century was the challenges to the ideological assumptions of the HayläSellassé regime, including who are the "true" Ethiopians? Who are the 
erstwhile leaders of the empire? What defines this empire? In this endeavor, many outside frameworks were employed by scholars and laypeople alike. One of the lenses, the colonial lens, interprets the late $19^{\text {th }}$-century Ethiopian empire as a colonial one, created through Western technology given to a quasi-African group to craft an indirect European colony (Asafa, 2005; Sisai and Holcomb, 1990 and Mekuria, 2011). In this vein, this colony produced identities that can be understood as colonial. The "Amhara" became civilized settlers, and all other groups became savage tribal natives, which the victory at Adwa cemented. Both identities were racial, thus, permanent and this colonial experience calcified these identities. Whether these identities existed before colonialism is inconsequential, as Mahmood Mamdani has proven in his work on Rwanda. He argues that Tutsi identity was imagined as foreign, racial, calcified, and civilized during the colonial era. At the same time, it was largely indigenous, ethnic, blurred, and class-based during the pre-colonial period ${ }^{1}$ (Mamdani, 2014). He concludes,

Did tribe exist before colonialism? If we understand by tribe an ethnic group with a common language, it did. But tribe as an administrative entity that distinguishes between natives and non-natives and systematically discriminates in favor of the former and against the latter - defining access to land participation in local governance and rules for settling disputes according to tribal identity - certainly did not exist before colonialism (Mamdani, 2012, p. 73).

These statements, if accurate, would make a native, settler dynamic impossible.

\section{9th-century identities in Menilek's Ethiopia}

The question for the first part of this essay is, did Menilek's Ethiopian empire produce the racialized tribal identities that determined both nativity and position in the realm? In his Du Bois lecture series, Mamdani writes, when discussing the Dutch East Indies,

The two categories [civilized and aboriginal] were identified with different rungs of the racial ladder: whereas Muslim Malay were officially acknowledgeable as civilized, civilized by religion; the Orang Asli, the aboriginal native, was consigned to the lowest rung of

${ }^{1}$ Historically, wealthy Hutu became Tutsi. See Mamdani, 2001, 70. 
the civilizational ladder. The civilized natives were not shy about claiming an exogenous origin, for it only served to confirm their right to rule, whereas the fully indigenous (asli) status of the Orang Asli implied that they are only fit to be subjects. (Mamdani, 2012, p. 33)

To apply this ideology to Menilek II's Ethiopian Empire, the Amhara would represent the civilized settler group, evidenced by their literacy, Christian religion, and Solomonic myth of exogenous legitimacy (Budge, 2007). While "native" groups like the largest ethnic group in Ethiopia, the Oromo would become the uncivilized natives. Most importantly, it renders these identities as immutable races and not elastic ethnic or cultural identities. A key component of colonial rule is manufacturing racial identities to obtain and maintain power. For example, Smedley argues that the British imagined the Irish as a separate racial group to rationalize the British conquest of parts of Ireland (Smedley and Smedley, 2001). To reiterate the question, what type of identities did Menilek II's empire create?

The $19^{\text {th }}$ century was one of upheaval in the Ethiopian highlands, where provincial authorities replaced the position of the emperor; Shäwa, the southernmost of these provinces, was independent of the emperor's power and in it rose Menilek's dynasty. Outside of the emperor's resources, the ruling house of Shäwa, mainly from the Mänz territory, crafted their domestic policies, aligned themselves with surrounding communities, and conducted their own foreign policy. The other regional houses, such as that of Wällo, Tigray, and Gojjam, were doing similar things throughout the $19^{\text {th }}$ century, which resulted in a great deal of integration between the groups in northern Ethiopia, including various Oromo groups. This situation did not cease with the mid- $19^{\text {th }}$ century designs of successive emperors, who dreamed of a centralized authority and a unified state. In the late $19^{\text {th }}$ century, a compromise was struck between the Tigrinyan speaking Emperor Yohannes IV, and the Amharic speaking Shäwan Menilek, establishing a loose confederacy of provinces that bridged the Zämäna Mäsafent to the modern aspirations of a unified state, which is seen in the victorious army at Adwa (Yates, 2020, p. 97-102). This compromise exchanged acceptance of Yohannes' imperial claims for a relatively free hand in Shäwa and surrounding areas and a marriage alliance between their children. ${ }^{2}$ It is in these surrounding areas where these colonial identities would be rooted.

\footnotetext{
${ }^{2}$ Menilek's daughter, Zäwditu, barely a teenager, was married to Yohannes' son Araya, who died before the marriage could produce a child. This potential child would have been undoubtedly a significant candidate for the throne.
} 
As presented in the Käbra Nagast, the Solomonic myth posits that Ethiopia's emperors are descended from the Israeli King Solomon, and the Ethiopian Queen Makeda, which, on the surface, argues for the foreignness of the "settlers" that were ruling Ethiopia. However, the actual practice of Shäwan conquest of surrounding areas due to erroneous views of reclaiming "lost" territories contradicted the "foreignness" of the settlers. For example, the wealthy province of Kaffa in Southern Ethiopia had medieval relations with the Ethiopian empire; evidence of these relations was utilized in rationalizing the conquest. In addition, the conquerors maintained that they found Christian material culture buried in the province of Kaffa as evidence of an influx of Christians in the territory during medieval times (Amnot, 1970, p. 269; Gebre-Sillasie, 2017, p. 354). These arguments were used for a native status for the Christian conquerors, not a foreign settler one. Regardless of whether the Shäwans were native to Kaffa (they were not), the fact that they crafted a narrative displays the lack of a desire to create a foreign settler identity.

However, both his dynasty and the regnal name of Menilek speak to using Solomonic descent to rationalize rule, and in terms of practice the passing of authority from father to son, the Shäwans were the most consistent of the major houses (Crummey, 1988). The successful passing of power needed alliances, which would be the true strength of the Shäwans. Still, the glue of these alliances is the integration of Shäwan groups into the upper echelons of political, military, and religious authority (Yates, 2020) The cultural consequence of this integration produced a syncretic culture that pulled from all of the Shäwan groups to the degree that at least the observer has argued that Shäwans are Oromos who speak Amharic (Markakis, 1975, pp. 48,71). These ties were cemented by marriage, which strengthened every generation through their children. While textual evidence of Shäwan affairs in the early $19^{\text {th }}$ century is scant, the documented and extensive marriages in the late $19^{\text {th }}$ century at the very least prove that these practices have a Shäwan precedent in addition to the fact that these alliances continued throughout the $19^{\text {th }}$ century and into at least the first half of the $20^{\text {th }}$ century (Bairu, 1972; Aleme, 1984; Heran, 2005).

Language, religion, and the military were crucial areas of acculturation, and the ways that conquered subjects became integrated into the power structure, generally at the top. Amharic became the second language for many non-native speakers, so much so that it fundamentally changed the language from the medieval version of the language to its modern iteration(Girma, 2013). Ethiopian Orthodox Christianity is an institution that was both a source of unity and a tool to keep the status quo. This status quo resulted from another alliance between the 
nobles, the church, and the military (Tsehai, 2018). The nobles contributed the funds and lands; the church insured the legitimacy, and the military provided the rewards in terms of lands and booty. Cavalry was the lifeblood of the $19^{\text {th }}$ century Ethiopian armies, Shäwa was no exception, and Oromo groups were vital in this part of the military, and it was a path that many Oromo took for authority throughout Ethiopia, especially in Wällo, Gojjam and Bägémder (Maimire, 2005, p. 274). The cavalry was essential in Menilek's victory at Adwa. According to some sources, Menilek himself highlighted it as the reason why they won (qtd. in Caulk, 2002, p. 563).

A clear parallel in North East Africa is the late $19^{\text {th }}$-century Mahdist State. This state was carved out of the Anglo-Egyptian Condominium and lasted for nearly two decades fighting against the Egyptians, British, and Ethiopians (Holt, 1970). Mamdani writes,

...it was the Mahdiyya that forged the basis of a common northern Sudanese identity. In addition, the Mahdiyya, especially the army often known as Dervish - had strong links in the south of Sudan. The key components of the army were the cavalry and the riflemen. The Dervish cavalry was drawn by and largely from the nomadic Baqqara, known to be fine horsemen or camel riders (2012, pp. 65-66).

This key parallel does not end here. The successor of the Mahdi, the Khalifa, also was not from Northern Sudan, rather a child of West Africans. In sum, identities throughout the Ethiopian empire were not racial, calcified, tribal, or locked. They were fluid, cultural, and by no means colonial. The Solomonic myth, even if accurate, the settlers purportedly from Arabia would be overrun by all the integrated "natives" who were leading the state. As Mamdani writes, "Kin relations are at the same time relations of power: "Kinship, as the tie binding communities together, tends to be regarded as the same thing with subjection to a common authority. The notions of Power and Consanguinity blend, but they in no ways supersede one another" $(2012$, p. 17). In other words, for the settlers to keep power over the natives, one must keep them separate. In Ethiopia, these integrative interactions were encouraged. However, a great deal of this information is not new, so why are these identities presented in a colonial manner in most scholars' work in the $20^{\text {th }}$ and $21^{\text {st }}$ centuries? The answer lies in power.

One of the definitions of history is the creation of a "usable" past. Thus, if one is trying to rationalize colonization, a version of the past must reinforce the legitimacy of colonial rule. Power is the central focus of Trouillot's classic text 
Silencing the Past, and here is where one finds the evidence for colonial identities in Menilek's Empire. First, Europeans imagined the "Amhara" as settlers, civilized, and non-African in order to reaffirm notions of white supremacy as opposed to its actual contradiction. In other words, if Africans cannot defeat Europeans in battle when Europeans lose, it cannot be to Africans (Marcus, 1971; Teshale, 1996; Yates, 2013). These ideas on African identities are bolstered by Ethiopia's historical and cultural ties to Jewish and Christian communities in the West. A generation before the term Africanist was applied to specialists on the African continent, specialists on Ethiopia were known as Semitists. The frame to understand the highland groups reinforced arguments for the savage, uncivilized nature of African natives, which rationalized colonial rule in other parts of Africa by imagining Ethiopia's ruling class as a settler group. ${ }^{3}$ Also, the Ethiopian empire's subjects were recast as natives to make them analogous to the created "natives" of the rest of the African continent.

To say it in different words, to make some Ethiopian groups non-African settlers, there needed to be African native subjects. In essence, scholars have argued that travelers and many $20^{\text {th }}$ century scholars assumed that all Africans were naturally "tribal" and put Ethiopian groups in line with how Africanists defined Africans (Allman, 2019, pp. 10-15; Yates, 2018). These ideas also have adherents in the $20^{\text {th }}$ and $21^{\text {st }}$ centuries. These scholars and politicians argue that the Ethiopian state is a colonial one where natives are imprisoned and ruled similarly to European colonies in Africa (Holcomb and Ibssa, 1990). Thus, they need their own states. This ideology transcends ethnicity, and Tigrinyan, Somali, and Oromo groups employ it to rationalize nationalist movements. A multi-ethnic victory at Adwa cannot be used as evidence for an ethno-nation.

Creating these narratives took a reinterpretation of Ethiopia's history and its identities. Because of the ethnonationalist narrative, fluid identities became calcified racial or tribal identities, and Shäwan conquests became ethnic. Oromo or Muslims who were integral to Ethiopia's history were marginalized and/or had their identities manipulated to create a colonial Ethiopian state. In Ethiopia, Amharic-speaking Oromos or Muslims were either ignored or turned into ethnic traitors, and with no power to protect their memory, were silenced in studies on Ethiopia. Also, with little no historical or current evidence, territories in Ethiopia

${ }^{3}$ There is some evidence that the recrafting of identity occurred within the society akin to J.D.Y. Peel's study on the Yoruba (Peel, 2000), however, most of the societal divisions prior to the $20^{\text {th }}$ century were place or religion based. For more on this issue see Yates (2020). 
Brian J. Yates

become tribal homelands, where, as Mandani writes in the 2019 New York Times article, ". . . the fiction of ethnic homeland creates endless minorities" (Mamdani 2019). For example, predominantly Muslim and Oromo Wällo is presently in the Amhara region, resulting in them becoming a minority in their own "ethnic" homeland.

Menilek's chronicle is one of the major primary sources of the period. It gives religious uniformity as the goal of Yohannes; however, it argues that it was unity for Menilek. For example, GäbraSellessé writes, "He spent six years to subject Wello [Wällo]. From then on, Shewa and Wello [Wällo] became as close and as united as the ilfiny [interior room] and addarash[reception room]" (GebreSillasie, 2017, p. 150). ${ }^{4}$ While Yohannes desired religious uniformity, saying years later, "Now all of you, whatever you may be, Muslims or Galla [this pejorative term seems to mean pagan in this context] believe in the name of Jesus Christ! Have yourselves baptized! If you wish to live in peace and hold on to your possessions, be Christian and live as Christians" (Gebre-Sillasie, 2017, p. 195). This policy changes the earlier statement of Menilek, who states, “. . these people from Wällo, although they are currently Muslims, shall become two or three years from now our brothers through baptism and communion. They can rule with us over this world . . . I want to attract the people of Wello [Wällo] through humility and charity and I want to teach them" (Gebre-Sillasie, 2017, p. 152). These policies are centered on religion, not on ethnicity or culture. Unfortunately for the Ethiopian canon, this subtlety is not reflected in the literature on Menilek's state, especially after the battle of Adwa.

The issue is writing back $20^{\text {th }}$ and $21^{\text {st }}$ concepts of identity and nation into the $19^{\text {th }}$ century. Trouillot writes, "History, as social process, involves peoples in three distinct capacities: 1) as agents or occupants of structural positions; 2) as actors in constant interface with a context; and 3) as subjects, that is, as voices aware of their vocality" $(2015$, p. 23$)$. In the case of Haiti, the victors of the only successful slave rebellion in human history also could not be African,regardless of the actual makeup of Haiti's avengers of the new world. Trouillot writes, "As the Auguste brothers [two French brothers who detailed the 1801-3 French military expedition to Haiti] have recently noted, no one wondered how the label "Congo" came to describe a purported political minority at a time when the bulk of the population was certainly African-born and probably from the Congo region"

\footnotetext{
${ }^{4}$ The meaning of this phrase is that in the dwellings of nobility, these rooms function in conjunction with each other, it would not make sense to have an outer room, if you did not have an inner room, and vice versa.
} 
(2015, p. 67). The rationale was the same. Just like Africans defeating Europeans in Africa is unthinkable, Africans doing the same in the New World is also an impossibility. Thus, the actions of "mulattos" literally, in terms of the jensd'coleur or culturally, including those with French names, are emphasized, while those with African names were silenced. The processes of imperial rule will be discussed later in this essay. Still, in terms of the identity frames, colonial authorities must also manipulate the identities of the "natives." In other words, the African actors in the Haitian revolution must be rebranded as Haitian, mulatto, or jend'coleur because their actions as Africans would both contradict 19th-century views on the potential of Africa as well as present notions of the Haitian state, regardless of what these actors actually said or did.

Mamdani renders "native" identities in the following way. First, they are, in the language of "racialized historiography," conceived as inherently tribal and a part of a race. He aptly puts it: "Tribalism is reified ethnicity. It is culture pinned to a homeland, culture in fixity, politicized, so that it does not move" $(2012$, p. 3). Permanence is critical in these identities and hence tying groups to a specific homeland. Also, settlers and natives must be members of different races and remain that way. These racial categories are compelling, especially as they align with the identities created in colonial Rwanda. So, the Tutsi or the Amhara are the civilized settler whose task is to civilize the natives (Hutu) or (non-Amhara). While not colonial subjects, they are imagined to play the role of the Tutsi in Rwanda or the Indian in South Africa and Uganda in civilizing the "natives" (Yates, 2018).Second, to calcify these identities, there needed to be a shift in frames; ethnicity as such became tribal, the diversity became simplified, especially that of the imagined "racial" groups. Therefore ethnic groups like the OmoticKafficho, Oromo and Somali were put into the same tribal category t. Even in present-day Ethiopia, the diversity of Ethiopia's Southern regions is subsumed under the banner of the Southern People's Region, and it is no surprise that these groups also want their own state. To create these natives, they needed to be unrelated to the settlers, uncivilized, tied to a homeland, tribal, and members of separate races.

Historically, these claims have little evidence, and as the largest Ethiopian group, the Oromo exemplifies Ethiopia's diversity and displays both continuity and change. They were a part of both the "settlers" and "natives" as outsiders have constructed them. Some of them were close relatives to the "settlers," others the actual "settlers," and still others with no familiar connections to the "settlers" (Maimire, 2005, p. 274). The Oromo are found throughout Ethiopia, speaking various languages, practicing many religions, and living in multiple ways. Maimire 
states, "Cultural, economic, social, religious and mythological factors as well as commerce, political alliances, and demographic movement have played important roles in the creation of Ethiopia as a shared historical space" (Maimire, 2005, p. 272). All of these realities contradict notions of native tribes in Ethiopia. Nevertheless, one does not need actual "natives" to treat populations as "natives," thus, the question that remains is, Did the Ethiopian empire treat subject populations as natives? In other words, was the nature of Ethiopian imperial administration in the $19^{\text {th }}$ century akin to the European colonies in the rest of the world?

\section{Colonial rule?}

Colonialism is not just an oppressive system of economic and political exploitation. It is also an epistemological system that redefines identities and histories. According to Mamdani, "tribal" administration has a few defining qualities. One is the lack of a single standard way to rule all colonial subjects. Two, there is an assumption that settlers and natives have to be governed by different frameworks, the migrant settlers by laws, the natives by custom. Three, the administrative practices reinforce these political categories of identity (Mamdani, 2012, 28-31, 42).

For the first element, the various systems of governance, Mamdani writes, "Transplanted to African colonies in the early twentieth century, the "customary" administrative authority classified the population in each unit ("tribal homeland") into natives and migrants, except this time both were ethnicized rather than racialized, with customary law privileging the ethnic native while discriminating against the ethnic migrant" (Mamdani, 2012, p. 7). ${ }^{5}$ In other words, the assumption is that colonial rule gives additional rights to natives concerning their homelands while at the same time denying them to settlers. These differences are rationalized by the consequences of the variations in identity between races and tribes. Again, Mamdani writes,

Non-natives were tagged as races, whereas natives were said to belong to tribes. Races were said to comprise all those officially categorized as not indigenous to Africa, whether they were indisputably foreign (Europeans, Asians) or whether their foreignness resulted from an official designation (Arabs, Colored, Tutsi). Tribes, in contrast, were all those defined as indigenous in origins . . . the

\footnotetext{
${ }^{5}$ These ideas are expanded upon in Mamdani, 2018.
} 
race tribe distinction cut through the single category - colonized - by politically distinguishing those indigenous from those foreign. (Mamdani, 2012. p. 47)

Mamdani argues here that indigeneity is politicized in how a subject is administered, which is then rendered into two different frames of identity, not just different identities. Both race and tribe are immutable identities. Race has significantly more variation within the category, but members of races can be civilized and civilize others. In contrast, those that are tribal are not civilized. Thus, one must determine identities for colonial administrations and treat them accordingly. In the case of tribes, it meant custom and "native" authorities (Mamdani, 2012, p. 25). Finally, these different types of administration cemented these imagined differences, creating the identities that are key to Africa's tribalism in the $21^{\text {st }}$ century. In sum, colonial administrations built their systems to divide, rule, and develop natives and settlers through their legal codes. The question is, did Menilek govern the same way?

\section{Administering the Ethiopian empire}

Modernization of Menilek's empire included finalizing borders, measuring all of the unmeasured lands, opening and developing trade routes, and solidifying regional alliances. The victory at Adwa ensured that Menilek could govern the state in the manner he wanted. These developments re-centered the empire on Shäwa under an ethnically diverse class of Habäsha officials, likely from Shäwa, which meant they had Oromo, Gurage, and "Amhara" descent (Getahun, 1974, p. 193). Two different administrations developed: one for the Northern provinces and another for the Southern areas. Menilek, like his Mänzé predecessors, created a personal style of leadership that incorporated sections on a case-by-case basis, and there was no indication of a racial or ethnic administration (Wellby, 1900, p. 295). Generally, if the submission was peaceful, the province was granted autonomy and the relationship usually cemented by intermarriage. If there was resistance, a province's autonomy would be eroded., forcing it under a loyal Shäwan governor.

In terms of administration, Menilek II had three distinct patterns of administration: The Oromos Jote and Kumsaa Moroda of Wällaga and Abba Jiffar of Jimma negotiated terms of their submission, which for Abba Jiffar solely meant a flat rate tribute payment every year, followed by entrance into Menilek's inner circle. (Gwynn, 1911, pp. 132-3; Jensen, 1905, p. 162) The second way was most notably seen in the rulers of Arsi Oromo and OmoKafa, who were the most difficult to subdue and eventually put under the rule of Menilek's family members Ras Dargé and Ras Wäldä Giyorgis and loyal Shäwan Habäsha like Fitawrari 
Häbtä Giyorgis and Däjazmach BalchaAbba Nafso (1866-1936), all veterans of the battle of Adwa. Another style was seen with Ras Mikaél and Nägus Täklä Haymanot, also veterans of Adwa, who were given gifts and marriage ties to maintain their loyalty (Caulk, 2002, p. 281). The final style occurred in the territories of Harar and Tigray. It was the least effective due to the appointments of outside rulers to these provinces and led to constant dismissals and nominations of various officials to these posts. Due to these differences that transcended ethnicity, it is impossible to argue that Menilek's rule was partially inspired by tribalism and created or maintained different racial identities.

Two seemingly contradictory practices are critical elements of colonial rule that separate from other rule types. One, the desire to assimilate all people in the empire. Two, the systematic exclusion of all subjects, native or settler, from the highest realms of political authority. Mamdani argues that racial civil laws discriminate against the racial settlers, like Asians in colonial Africa and that natives are discriminated against in customary law and thereby doubly oppressed. (Mamdani, 2012, p. 50) .The separation of natives from settlers and colonialists is precisely why marriages between colonial officials and natives were banned in colonial law. Mamdani continues, "Kin relations are at the same time relations of power: Kinship, as the tie binding communities together, tends to be regarded as the same thing with subjection to a common authority. The notions of Power and Consanguinity blend, but they in no ways supersede one another." (Mamdani, 2012, p. 17) Limiting this power to a particular group was key to colonial practice, and restricting access via kinship ties went hand in hand with ruling.

Race as a framework for identity has always been intertwined with power. This power is dependent upon the maintenance of firm boundaries between racial groups. These boundaries are maintained at all levels, especially in the upper classes. For example, up until the 20th-century European royalty only married within the established monarchal bloodline. These notions were transported to their colonies, where traditional practices of utilizing elite marriage between conquered and conquerors were reversed to maintain racial "purity." In Carina Ray's excellent study on interracial relations in colonial Gold Coast, it is argued that the practice of marriage in this territory worked to prove the distance between Europeans and Africans, define future generations and protect the purity of the European race (2015, pp. 6-16). A reversal in these practices coincided with challenges to local authority and the redefining of colonial interaction as solely one-sided. In essence, marriages that were fruitful to colonial subjects and officials because they acknowledged multiple power sources and created fluid boundaries were reversed to maintain the colonial order and thus acknowledge only one source 
of authority. Rayfurther relates that the precedent for British reversals of traditional interactions is seen in both French and Portuguese policies in West Africa(2015, pp. 31-9). She articulates, “. . a new emphasis was placed on the creation of racial boundaries as a means of consolidating colonial rule" (Ray, 2015, p. 10). The consequences of this power consolidation are segregation, limiting posts to Europeans, discrimination in almost all colonial sectors to ". . . bring interracial fraternization to an end" (Ray, 2015, p. 10).

In the Ethiopian case, the practice was the opposite. There was no desire or ability to exclude the empire's subjects. Still, there was also systematic inclusion of all elites, regardless of ethnicity, into the highest forms of authority, up to and including the emperor. While most of the conquest of the surrounding regions of Shäwa is undocumented, there is an account of the Battle of Embabo in Menilek's chronicle, which exemplifies Oromo integration into the empire. This battle was between Gojjam and Shäwa, led by Oromo generals, over the path to conquering territories that make up most of South-Western Ethiopia. Menilek's forces were victorious due to the addition of Mas'ewot's Muslim Oromo Wällo forces, as well as the military tactics of the Oromo Ras Gobäna (Girma, 2014, p. 163). While the course of the battle displays the widespread integration of both Oromo and Muslims, the consequences are even more telling. Many Gojjamé prisoners of war were first given to Ras Gobäna and later to another Oromo of the recently conquered region of Jimma, Fitwrari Qidada, who was also entrusted with the confiscated firearms (Gebre-Sillasie, 2017, pp. 226-7). So, if the desire is to render natives as different races from the colonizer, this policy of empowering "natives" over colonizers would accomplish the opposite.

Another example is the awaj to obtain troops for the campaign at Adwa, was "of a black [Menilek's expanded state] snake's bite, you may be cured, but from the bite of a white [European colonization] snake, you will never recover" (Berkeley, 1935, pp. 12). Undoubtedly a politically self-serving statement, it does reflect that the conquerors see themselves as members of the same race as those they conquered. In addition, during the lead up to Adwa in 1894, in a territory near the battlegrounds, after cutting telephone lines to interrupt communications in Eritrea, Bahta Hagos, an Eritrean colonial governor, stated the following for his Italian superior, "You with eyes of a cat, hair of a monkey and with white lips. .." (Caulk, 1986, pp. 301). This statement is again highlighting the racial differences between European colonizers and Ethiopians. Menilek's administration blurred the lines between Afan Oromo speakers and Amharic speakers, Muslim and Christian, "native" and settler. There may be evidence that Menilek calcified the lines 
between Christian Amharic speaking groups such as the Shäwan Amhara and the Gojjames, and Habäsha groups, like the Tigrinyans and Amharas

Menilek's Ethiopia was initially organized via personal relationships that transcended ethnicity, and when it did not, it often worked against fellow highlanders. For example, a recurring theme in 19th and 20th century Ethiopian history is the conflicts between Tigray and Shäwa. Both of these territories are a part of old Abyssinia and Habäsha, but the treatment of Tigrinyan populations contradicts theories of colonialism (Mekonnen, 1994; Alema, 1978). First, unlike many other territories, Menilek appointed Shäwans over the indigenous nobility. These appointments were largely unsuccessful, but this contentious relationship remained throughout the 20th century and was also seen in the reincorporation of Eritrea during Haylä Sellassé's reign.

At the time that the Käbra Nagast was purportedly written, the Aksumite state was controlling significant parts of the highlands, and for centuries emperors were crowned in Aksum. Menilek was crowned emperor in his native province, Shäwa, in his capital at the time, Ent'ott'o, in 1888. While the Käbra Nagast establishes Tigray as the mythical center of this settler state, but in Menilek's empire, it was treated like a "native" state. This type of treatment is echoed in Harar, Kaffa, and Arsi, but not in Jimma, Wälläga, and Wällo. If assimilation was Menilek's goal, it would have appointed settlers over natives, not vice versa. Also, even in the centralization efforts of Menilek, provincial elites, "native" power increased at the expense of "settler" power. In other words, native elites like that of Wälläga,,Jimma and Wällo were empowered over settlers While these elements may seem illogical, they have precedent, the Roman Empire.

In his discussion of the administration of the Roman empire, Mamdani argues for three main elements for its administration. One, the integration of traditional provincial elites and rule via custom.Two, the eventual leadership of the empire came from the provinces as opposed to the center. And three, a syncretic culture of the kingdom that produced peace in the provinces, a stooping down of imperial culture, and extensive kinship bonds. In terms of laws, Mamdani writes, "Their (Roman Empire) ambition to spread civil law through the assimilation of new elites gave way to a customary pact with old elites" (Mamdani, 2012, p. 75). This shift was a result of a philosophy on identity. Instead of creating and maintaining strict boundaries of identity they opened up "Romanness" to native elites throughout the empire. While with the Greeks, "... . the barrier with barbarians was 'clear-cut and difficult to cross,' Romans thought of it as "a continuum along which it was relatively easy to progress." (Mamdani, 2012, p. 80) Because of these views, it was significantly easier for non-Romans to become 
Romans, and the consequences were political, cultural, and religious. These views of identity are devoid of race (because it was not invented yet) and notions of tribe or innate superiority and accelerated both the path to citizenship and the change in the culture of the imperial center.

In Ethiopia, the processes culminated in several ways. First, it created a stake for provincial elites, who not only peacefully governed their territories, but rose to the highest realms of political authority. It also produced opportunities to display that power, like that of Adwa. The major Ethiopian houses, provinces, religions played vital roles in this Ethiopian victory. The consequences of integrating provincial elites are significant. Mamdani writes, "The remarkable fact was that no troops were needed to hold down the cities in the east because the most powerful of the local citizens, men to whom Rome had granted equality of rights, kept order and ensured loyalty" (Mamdani, 2012, p. 78). British colonialism resulted in significant examples of rebellion, especially in settler states, none more famous than Mau Mau. The Haitian Revolution also speaks to the naturalness of rebelling against a system in which you do not have a stake. This integration also reshaped the empire culturally, socially, and politically (Mamdani, 2012, p. 76). Mamdani writes, "Rome became multicultural. In spite of its name, the empire was less and less Roman. In the third century, most senators were not Italians. From Trajan onward, most emperors came from the provinces. The eternal city celebrated its millennium in AD 247 under the rule of an Arab Sheikh." Going back to the title of Mamdani's work, Define and Rule, the Roman Empire in the 3rd century would be better put as The Natives Redefining the Empire and Ruling It. These three processes all occurred in Menilek's Ethiopia.

Over the last several centuries, changes in Ethiopia show that the Habäsha identity was one where the various groups could easily become, and the last few centuries are compelling evidence (Tadesse 1988a, 1988b; Quirin 1992; Yates, 2020).Oromos, Tigrayans, Gafats, Agaws, Muslims all became Habäsha and kin. The participation in the victory at Adwa cemented these identities by displaying their presence as a clear message of their role in the empire. As mentioned earlier, the conquered elites became parts of the Menilek's inner circle, connected by marriage and continued through their children's destinies. In Menilek's Ethiopia, the integration of the provincial elites occurred within a generation as Menilek's heirs were from all of the provinces. Wässan Säggad, the grandson of Menilek, and Menilek's most important general, Ras Gobäna was the first choice. and; after his death, Menilek II selected the son of another "native" elite, the former Muslim, the Wällo Oromo Ras, Mikaél. The resultant political culture resembled Rome, and as Mamdani puts it, ". . . the alternative is to see both involved in a mutually 
transforming process. Because the final product partakes both, no matter how unequally, and does not quite resemble either, the process is also identitytransforming for both sides." (Mamdani, 2012, p. 82) This is a sufficient concluding point. Fundamentally colonialism, in theory, is about change in only one direction, to make the native and settler more like the colonizer, never in the other direction.

\section{Conclusion}

The oppression that accompanied the expansion of the Ethiopian state after the victory at Adwa in the late $19^{\text {th }}$ century was excessive and incredibly exploitative, but of a completely different nature than colonial oppression because identities were not reshaped to make power exclusive to one group. Undoubtedly, it was advantageous to be an Habäsha, but the boundaries remained fluid throughout the $20^{\text {th }}$ and $21^{\text {st }}$-century. Menilek's state was built by incorporating regional elites, regardless of their identities. Menilek's Ethiopia possessed many practices that brought about integration instead of colonial segregation; these practices attractedmany diverse people to Menilek's empire, which all took part, as the victory at Adwa attests. The precedent of Menilek's late $19^{\text {th }}$-century state is not found in the European colonial exclusion but rather in the empires that preceded the invention of race. As many scholars have noted, European colonial empires created identities to maintain a colonial order. These colonial orders made and remade identities to keep power and civilization with the colonizer, create permanent boundaries between conquered and conqueror, and reshape the reality of the vanquished. These arguments are a significant break from $20^{\text {th }}$ and $21^{\text {st }}$ century scholarship because there is no power behind a non-ethnic Ethiopian empire. The Ethiopian state, especially after the downfall of Mengistu Haile Mariam, created and invoked an ethnic state to hold on to power. This same power is challenged along with identity frameworks, especially that of ethnicity to this day. This challenge to the state reifies these same ethnic frames by rewriting history along ethnic lines, ignoring the nature of Menilek's conquest, oppression, and empire. In the last part of Mamdani New York Times editorial, he states, "Neither the centralized republic instituted by the Derg military junta in 1974 nor the ethnic federalism of Mr. Zenawi's 1994 Constitution points to a way forward" (Mamdani 2019). Perhaps, a look back at the identities of Menilek's Ethiopia can produce a state that can return Ethiopia to global prominence. 


\section{References}

Aleme Eshete. (1978). Struggle for power: Tigrai (Ras Mengesha) versus Shoa (King Menelik) 1889-98. Miscellanea 2. Institute of Ethiopian Studies.

Aleme Eshete. (1984). Political marriage and divorce in Ethiopian history (late 19th and early 20th century) (Unpublished manuscript). Institute of Ethiopian Studies.

Allman, J. M. (2019). \#HerskovitsMustFall? A meditation on whiteness, African studies, and the unfinished business of 1968. African Studies Review, 62(3), 6-39.

Amnot Orent. (1970). Refocusing on the history of Kafa prior to 1897: A discussion of political processes. The Journal of African History, 3(2), 263293.

Asafa Jalata. (2005). Oromia and Ethiopia: State formation and ethnonational conflict, 1868-2004. Red Sea Press.

Bairu Tafla. (1972). Marriage as a political device: An appraisal of a social aspect of the Menelik II period (1889-1916). Journal of Ethiopian Studies, X (1), $13-22$.

Berkeley, G.F.H. (1935). The campaign of Adowa and the rise of Menelik. Constable and co.

Budge, E. A. W. (2007). The Kebra Nagast: The Queen of Sheba and her only son Menyelek (Forgotten Books). Forgotten Books.

Caulk, R. A. (2002). "Between the jaws of hyenas": A diplomatic history of Ethiopia (1876-1896) (B. Zewde, Ed.). Harrassowitz.

Caulk, R.A. (1986). 'Black snake, white snake': Bahta Hagos and his revolt against overrule in Eritrea, 1894. In Crummey, D. (Ed.), Banditry, rebellion and social protest in Africa. Currey.

Crummey, D. (1988). Imperial legitimacy and the creation of neo-Solomonic ideology in 19th century Ethiopia. Cahiers d'Etudes Africaines, 109(28), $13-43$.

Gebre-Sillasie.(2017). Chronicle of the Reign of Menilek II, King of Kings of Ethiopia (M. de Coppet, Ed.; TesfaSillasie \& D. Lussier, Trans.; 1st ed., 2 Vol.).Tsehai Publishers.

Getahun Dilebo. (1974). Emperor Menilek's Ethiopia, 1865-1916: National unification or Amhara communal domination [Ph.D. dissertation]. Howard University.

Girma Getahun. (Ed. And Trans.). (2014). The Goggam chronicle (Translation edition). British Academy.

Girma Demeke. (2013). The origin of Amharic. Red Sea Press. 
Brian J. Yates

Gwynn, C. W. (1911). A journey in southern Abyssinia. Geographic Journal, $38(2), 113-139$.

Heran Sereke-Brhan. (2005). "Like adding water to milk": Marriage and politics in nineteenth-century Ethiopia. The International Journal of African Historical Studies, 38(1), 49-77.

Holcomb, B. K., \& Sisai Ibssa. (1990). The invention of Ethiopia. Red Sea Press.

Holt, P. M. (1970). The Mahdist state in the Sudan, 1881-1898: A study of its origins, development and overthrow. Clarendon P.

Huntingford, G. W. B. (1969). The Galla of Ethiopia: The kingdoms of Kafa and Janjero. International African Institute.

Jensen, B. H. (1905). South-western Abyssinia. Geographic Journal, 25(2), 158171.

Mamdani, M. (2012). Define and rule: Native as political identity. Harvard University Press.

Mamdani, M. (2014). When victims become killers: Colonialism, nativism, and the genocide in Rwanda. Princeton University Press.

Mamdani, M. (2018). Citizen and subject: Contemporary Africa and the legacy of late colonialism (New edition). Princeton University Press.

Mamdani, M. (2019, January 3). Opinion: The trouble with Ethiopia's ethnic federalism. The New York Times. https://www.nytimes.com/2019/01/03/opinion/ethiopia-abiy-ahmedreforms-ethnic-conflict-ethnic-federalism.html

Marcus, H. G. (1971). The black men who turned white: European attitudes towards Ethiopians, 1850-1900. Archiv Orentalni, 39, 155-166.

Markakis, J. (1975). Ethiopia: Anatomy of a traditional polity. Oxford University Press.

Maimire Mennasemay. (2005). Ethiopian history and critical theory: The case of Adowa. In P. Milkias, \& G. Metaferia (Eds.), The battle of Adowa: Reflections on Ethiopia's historic victory against European colonialism (pp. 265-280). Algora Publishing.

Mekonnen Berhanu. (1994). A political history of Tigray: Shewan centralism versus Tigrean regionalism (1889-1910) [Master's thesis], Addis Ababa University.

Mekuria Bulcha, (2011). Contours of the emergent and ancient Oromo nation: Dilemmas in the Ethiopian politics of state and nation-building. Center for Advanced Studies of African Societies.

Peel, J. D. Y. (2000). Religious encounter and the making of the Yoruba. Indiana University Press. 
Quirin, J. A. (1992). The evolution of the Ethiopian Jews: A history of the Beta Israel (Falasha) to 1920. University of Pennsylvania Press.

Ray, C. E. (2015). Crossing the color line: Race, sex, and the contested politics of colonialism in Ghana. Ohio University Press.

Smedley, A. (1993). Race in North America: Origin And Evolution Of A Worldview. Westview Press.

Smedley, A., \& Smedley, B. D. (2011). Race in North America: Origin and evolution of a worldview. Westview Press.

Taddese Tamrat. (1988a). Processes of ethnic integration and integration in Ethiopian history: The Case of the Agaw. Journal of African History, 29, 518.

Taddese Tamrat. (1988b). Ethnic interaction and integration in Ethiopian History: The case of the Gafat. Journal of Ethiopian Studies, 21(1), 121-154.

Teshale Tibebu. (1996). Ethiopia: The "anomaly" and "paradox" of Africa. Journal of Black Studies, 26(4), 414-430.

Trouillot, M.-R. (2015). Silencing the past power and the production of history. Beacon Press.

Tsehai Berhane-Selassie. (2018). Ethiopian warriorhood: Defence, land and society 1800-1941. James Currey.

Wellby, M. S. (1900). King Menelek's dominions and the country between lake gallop (Rudolf) and the Nile Valley. Geographic Journal, 16(3), 292-304.

Yates, B. J. (2018). Ethiopian categories, British definitions: British discovery of Ethiopian identities from the nineteenth century to the first decade of the twentieth century. Northeast African Studies, 18(1-2), 231-270.

Yates, B.J. (2015). From hated to Häbäsha: Oromo identity shifts in Wällo and Shäwa during the late nineteenth century. African Identities, 14(3), 194-208.

Yates, B. J. (2013). From white males to black females understanding the national bodies of Ethiopia (1896-1936). Journal of Black Studies, 44(1), 81-100.

Yates B. J. (2020) The other Abyssinians: The Northern Oromo and the creation of modern Ethiopia. University of Rochester Press. 